\title{
Ingredients Analysis and Biological Activity of Fermented Angelica gigas Nakai by Mold
}

\author{
Jae Young Cha, Hyun Woo Kim, Jin Sun Heo ${ }^{1}$, Hee Young Ahn ${ }^{2}$, Kyung Eun Eom², \\ $\mathrm{Su}$ Jin $\mathrm{Heo}^{2}$ and Young Su Cho ${ }^{3 *}$
}

Technical Research Institute, Daesun Distilling Co., Ltd. Busan 619-934, Korea

${ }^{1}$ Sancheong Institute of Medicinal Herb on Foundation, Gyeongsangnam-do 666-802, Korea

${ }^{2}$ Department of Biosciences, Graduate School, Dong-A University, Busan 604-714, Korea

${ }^{3}$ Department of Biotechnology, Dong-A University, Busan 604-714, Korea

Received July 9, 2010 /Accepted September 13, 2010

\begin{abstract}
Three mold strains, Aspergillus oryzae (AOFAG), Aspergillus kawachii (AKFAG), and Monascus purpureus (MPFAG) were used for fermentation of Angelica gigas Nakai powder. The contents of polyphenolic compounds, flavonoids, minerals, decursin and decursinol angelate and the activities of DPPH $(a, a$ '-diphenyl- $\beta$-picrylhydrazyl) free radical scavenging, reducing power, and tyrosinase were measured. The highest contents of phenolic compound and flavonoid were NFAG at $2.78 \%$ and MPFAG at $1.18 \%$, respectively. Major minerals were $\mathrm{K}, \mathrm{Mg}, \mathrm{Fe}, \mathrm{Na}$ and $\mathrm{Ca}$. Decursin and decursinol angelate were the major ingredients of Angelica gigas according to HPLC analysis. Decursin area was higher in all fermented Angelica gigas than in NFAG. The activities of free radical scavenging and tyrosinase were stronger in all fermented Angelica gigas than NFAG. However, the Fe/Cu reducing powers were stronger in NFAG than all fermented Angelica gigas. Overall, these results may provide the basic data needed to understand the biological activities and chemical characteristics of Angelica gigas fermented by mold for the development of functional foods.
\end{abstract}

Key words : Fermented-Angelica gigas Nakai, decursin, decursinol angelate, antioxidation, tyrosinase

\section{서 론}

참당귀(Angelica gigas Nakai)는 미나리과(Umbelliferae)에 속하는 다년생 초본으로 주로 한국, 중국, 일본에 분포하고 있으며, 각 지역에 따라 재배하여 생약 재료로 사용되고 있다. 우리나라에서 재배되고 있는 참당귀는 중국당귀(Angelica sinensis Diels), 일본당귀(Angelica acutiloba Kitagawa)와 구분되 고 있다. 참당귀는 예로부터 질병치료와 건강증진 목적으로 사용 해온 우리나라의 대표적인 생약재로서 감초 다음으로 많이 처방되고 있다[12]. 특히 우리나라에서 재배되고 있는 참 당귀는 부인과 질환에 널리 사용됨으로서 여성들에게 유효한 약재로 인식되고 있다.

국내에 재배되고 있는 참당귀의 약효성분으로는 decursin, decursinol, decursinol angelate, nodakenetin, nodakenin, umbelliferone, $\beta$-sitosterol, a-pinene, limonene 등이 함유되 어 있다[13,20,32]. 이들 성분은 항산화 작용[18], 주름개선, 조 직 재생 및 tyrosinase 저해에 의한 미백 작용[16,17], 항암작용 [28], 알코올 대사 촉진작용 및 간질환 개선작용[25]을 가지고 있는 것으로 보고되었다.

\footnotetext{
*Corresponding author

Tel : +82-51-200-7586, Fax : +82-51-200-7505

E-mail : choys@dau.ac.kr
}

특히 참당귀의 주요 성분인 decursin 및 decursinol angelate는 부위별, 지역별 및 추출 방법에 따라서도 함량이 달라지 며, 국내산 참당귀가 중국산당귀 및 일본산 당귀 보다 많이 함유되어 있는 것으로 분석되었다[28,32]. 이러한 주된 이유로 는 국내산 참당귀가 한방 처방전에 주로 사용되고 있는 가운 데 지역에 따른 재배환경 차이에 의해서도 약효성분 함량이 달라지기 때문에 우리나라에서 청정지역 중 하나로 알려진 지리산 일대에서 재배되고 있는 참당귀가 주목 받게 되었다 [22,33].

한편, 기능성 식품 또는 기능성 화장품을 개발하는 과정에 서 사용되고 있는 당귀, 뽕잎과 같은 식물 추출물은 그 자체가 독성 작용을 나타내는 경우가 종종 있으며 $[17,30]$, 미생물 또는 버섯균사체로 발효 시킴으로서 독성이 경감되는 동시에 발효 산물에 의해 혈중 지질저하 작용, 항산화 작용, tyrosinase 활 성 저해 및 멜라닌 생성 억제 작용, 혈전용해 작용 등이 증가되 며, 이 때 발효에 의해 새로운 물질이 생성되거나 기존의 생리 활성 물질이 다른 물질로 전환시켜 처음과는 다른 효능을 가 지게 됨으로서 이러한 기능성 향상 연구가 시도되고 있다 $[6,39]$.

따라서 본 연구에서도 우리나라에서 청정지역 중 하나로 알려진 지리산 일대에서 많이 재배되고 있는 참당귀의 이용 가치를 향상시킬 목적으로 다량의 탄수화물을 함유 $[28,35]$ 한 
당귀 뿌리를 발효시키기 위하여 3 종류의 곰팡이 균주, Aspergillus oryzae, Aspergillus kawachii 및 Monascus purpureus 로 발효시킨 발효 당귀의 생리활성 물질 및 그 활성에 대하여 검토하였다.

\section{재료 및 방법}

\section{실험재료 및 발효 조건}

본 실험에 사용한 참당귀(Angelica gigas Nakai)는 2009년 9월에 경상남도 산청군 지리산 일대에서 재배되고 있는 것을 농가로부터 직접 구입하여 뿌리를 깨끗하게 물로 씻은 후 흙 과 이물질을 제거하고 건조시켜 분쇄 후 시료로 사용하였다. 참당귀 분말 시료에 3종류의 곰팡이 균주 Aspergillus oryzae KCCM 11372, Aspergillus kawachii KCCM 32819 및 Monascus purpureus KCCM 12002를 한국미생물보존센터로부터 분양 받아 참당귀 발효에 사용하였다. 세 균주의 seed culture는 glucose $10 \%$, peptone $5 \%, \mathrm{KNO}_{3} 2 \%, \mathrm{NH}_{4} \mathrm{H}_{2} \mathrm{PO}_{4} 2 \%$, $\mathrm{MgSO}_{4} \cdot 7 \mathrm{H}_{2} \mathrm{O} 0.5 \%$ 및 $\mathrm{CaCl}_{2} 0.1 \%$ 함유 배지에서 $30^{\circ} \mathrm{C}, 150$ $\mathrm{rpm}$ 으로 72 시간 배양한 후 참당귀 분말에 각각 $5 \%(\mathrm{v} / \mathrm{w})$ 수 준으로 첨가하여 $30^{\circ} \mathrm{C}$ 에서 12 일간 고체배양 시켰다.

\section{Decursin 및 decursinol angelate 함량 측정}

원료 참당귀 및 발효 참당귀 분말의 20 배에 해당하는 메탄 올로 2시간씩 5회 환류 추출 한 다음 Sartorius Minisart 0.45 $\mu \mathrm{m}$ filter (Sartorius Stedim, Goettingen, Germany)로 여과 한 후 진공농축기(Buchi Rotavapor R-215)로 농축하였다. 농축된 시료를 메탄올로 녹인 다음 Sartorius Minisart $0.2 \mu \mathrm{m}$ filter (Sartorius Stedim, Goettingen, Germany)로 여과시킨 후 분석 시료로 사용하였다. 메탄올에 녹인 시료는 HPLC-DAD (Agilent 1200, Agilent Techologies, USA)를 사용하였으며, 컬 럼은 Waters symmetry C18 column $(4.5 \times 250 \mathrm{~mm}, 5 \mu \mathrm{m})$, 용 매 A는 HPLC용 water, 용매 B acetonitrile을 사용하여 gradient 조건으로 분석하였다[2]. 분석 조건은 Table 1 과 같이 column oven 온도 $25^{\circ} \mathrm{C}$, 이동상의 속도 $1 \mathrm{ml} / \mathrm{min}, \mathrm{DAD}$ 분석 파장은 $328 \mathrm{~nm}$ 로 용매 gradient 조건으로 분석하였다.

\section{Polyphenolic compounds 함량 측정}

Polyphenolic compounds의 함량은 Folin-Denis법[36]으로 측정하였다. 발효 당귀 분말의 $0.1 \%(\mathrm{w} / \mathrm{v})$ 시료 용액 $0.5 \mathrm{ml}$ 에 Folin-ciocalteu's phenol reagent $2.5 \mathrm{ml}$ 를 첨가하여 잘 혼합하 고, 실온에서 정확히 5 분 반응시킨 후 $7.5 \% \mathrm{Na}_{2} \mathrm{CO}_{3} 2 \mathrm{ml}$ 를 가하 여 혼합하고, $50^{\circ} \mathrm{C}$ 에서 5 분간 발색시킨 다음 Spectrophotometer (HITACHI U-2900, Hitachi High-Technologies Co., Kyoto, Japan) $760 \mathrm{~nm}$ 에서 흡광도를 측정하였다. 이때 polyphenolic compounds의 함량은 tannic acid를 0-500 $\mu \mathrm{g} / \mathrm{ml}$ 농도로 하여 시료와 동일한 방법으로 측정한 표준곡선으로부터 계산하였다.
Table 1. Solvent gradient condition for HPLC-DAD

\begin{tabular}{cccc}
\hline $\begin{array}{c}\text { Time } \\
(\mathrm{min})\end{array}$ & $\begin{array}{c}\text { Flow rate } \\
(\mathrm{ml} / \mathrm{min})\end{array}$ & $\begin{array}{c}\text { Solvent A } \\
(\%)\end{array}$ & $\begin{array}{c}\text { Solvent B } \\
(\%)\end{array}$ \\
\hline 0 & 1.0 & 80 & 20 \\
3 & 1.0 & 80 & 20 \\
8 & 1.0 & 70 & 30 \\
18 & 1.0 & 70 & 30 \\
19 & 1.0 & 50 & 50 \\
40 & 1.0 & 50 & 50 \\
41 & 1.0 & 0 & 100 \\
50 & 1.0 & 0 & 100 \\
\hline
\end{tabular}

\section{Flavonoid 함량 측정}

Flavonoid 함량은 Jia 등[15]의 방법에 따라 측정하였다. 발 효 당귀 분말의 $0.1 \%(\mathrm{w} / \mathrm{v})$ 시료 용액 $0.25 \mathrm{ml}$ 에 $1.25 \mathrm{ml}$ 의 정제수와 $5 \% \mathrm{NaNO}_{2}$ 용액 $5 \mathrm{ml}$ 을 가하고, 5 분 후 $10 \% \mathrm{AlCl}_{3}$ $6 \mathrm{H}_{2} \mathrm{O} 0.15 \mathrm{ml}$ 를 잘 혼합한 후 Spectrophotometer (HITACHI U-2900, Kyoto, Japan)의 $510 \mathrm{~nm}$ 에서 흡광도를 측정하였다. 이 때 플라보노이드 함량은 표준 물질로서 (+)-catechin hydrate을 20 200 $\mu \mathrm{g} / \mathrm{ml}$ 농도로 시료와 동일한 방법으로 측정 하여 작성한 표준곡선으로부터 계산하였다.

\section{$\mathrm{DPPH}$ 에 의한 항산화 활성 측정}

항산화 활성 측정은 $\mathrm{Abe}$ 등[1]의 방법에 따라 측정하였다. $\mathrm{DPPH}$ (a, $\mathrm{a}^{\prime}$-diphenyl-ß-picrylhydrazyl) $16 \mathrm{mg}$ 을 에탄올 100 $\mathrm{ml}$ 에 녹인 후 동량의 증류수를 혼합하여 Whatman filter paper NO. 2에 여과시켜 반응 용액을 제조하였다. 발효 당귀 분말의 $0.05 \%(\mathrm{w} / \mathrm{v})$ 시료 용액 $1 \mathrm{ml}$ 을 취하고, 여기에 $\mathrm{DPPH}$ 반응 용액 $5 \mathrm{ml}$ 을 넣어 잘 혼합한 후 암소에서 30 분간 반응시 킨 후 Spectrophotometer (HITACHI U-2900, Kyoto, Japan)의 $528 \mathrm{~nm}$ 에서 흡광도를 측정하였다. 이때 활성 비교를 위하여 기존에 항산화제로 많이 사용되고 있는 합성 항산화제 BHT를 $0.05 \%$ 농도로 첨가하여 시료와 동일한 방법으로 흡광도를 측 정하였다. $\mathrm{DPPH}$ 를 이용한 항산화 활성은 시료 첨가구와 무첨 가구의 흡광도차를 백분율(\%)로 표시하였다.

DPPH radical scavenging activity $(\%)=[1$-(sample absorbance $528 \mathrm{~nm}$ )/ control absorbance $528 \mathrm{~nm}] \times 100$

\section{미네랄 함량 측정}

발효 당귀 분말의 미네랄 함량은 $\mathrm{AOAC}$ 분석 방법에 준하 여 측정하였다. 각 분말 $1 \mathrm{~g}$ 을 정확히 취해 각 $550^{\circ} \mathrm{C}$ 회화로에 서 3시간 회화 시킨 후 $6 \mathrm{~N} \mathrm{HCl}$ 에 용해시켜 완전히 산 분해시 켜 수욕상에서 산을 완전히 제거하고, 이 건고물에 $3 \mathrm{~N} \mathrm{HCl}$ 을 가하여 여과한 후 원소 종류에 따라 각각 일정비율로 희석하 여 원자흡광 분광광도계(AAnalyst 300, Perkin Elmer, Norwalk CT, USA)를 이용하여 측정하였다. 


\section{$\mathrm{Fe} / \mathrm{Cu}$ 환원력 측정}

$\mathrm{Fe}$-환원력 측정은 $\mathrm{Zhu}$ 등[41]의 방법에 따라 측정하였다. 발효 당귀분말의 $0.05 \%(\mathrm{w} / \mathrm{v})$ 시료 용액 $0.75 \mathrm{ml}$ 을 취하고, $0.2 \mathrm{M}$ sodium phosphate buffer ( $\mathrm{pH}$ 6.6) $1.25 \mathrm{ml}$ 및 $1 \%$ $(\mathrm{w} / \mathrm{v})$ potassium ferricyanide $\left[\mathrm{K}_{3} \mathrm{Fe}(\mathrm{CN})_{6}\right] 1.25 \mathrm{ml}$ 을 혼합 하여 $50^{\circ} \mathrm{C}$ 에서 20 분간 진탕반응 시켰다. 이 반응액에 $10 \%$ trichloroacetic acid $(\mathrm{w} / \mathrm{v})$ 를 $1.25 \mathrm{ml}$ 가하여 acidified 시키 고, 3,000 rpm에서 20분간 원심분리 시켰다. 상층액 $2.5 \mathrm{ml}$ 를 취하고 distilled water $2.5 \mathrm{ml}$ 및 $0.5 \%$ ferric chloride $\left(\mathrm{FeCl}_{3}\right) 0.5 \mathrm{ml}$ 를 혼합한 후 실온에서 10분간 반응 시켜 Spectrophotometer (HITACHI U-2900, Kyoto, Japan)의 700 $\mathrm{nm}$ 에서 흡광도를 측정하였다.

한편, $\mathrm{Cu}$-환원력 측정은 발효 당귀 분말의 $0.05 \%(\mathrm{w} / \mathrm{v})$ 시 료 용액 $0.2 \mathrm{ml}$ 를 취하고 $0.01 \mathrm{M} \mathrm{CuCl}_{2} 0.25 \mathrm{ml}, 7.5 \mathrm{mM}$ ethanolic neocuprorine solution $0.25 \mathrm{ml}, 1 \mathrm{M} \mathrm{NH}_{4} \mathrm{OAc}$ buffer 0.25 $\mathrm{ml}$ 를 혼합하여 distilled water $1.05 \mathrm{ml}$ 를 넣은 후 상온에서 30 분간 반응시킨 후 $420 \mathrm{~nm}$ 에서 흡광도를 측정하였다. 이때 환원력 비교를 위하여 기존에 항산화제로 많이 사용되고 있는 천연 항산화 ascorbic acid와 합성 항산화제 BHT를 각각 시료 와 동일 농도로 동일한 방법으로 흡광도를 측정하였다. 환원 력은 시료 반응액에서 흡광도가 증가된 만큼 강한 환원력을 나타내어 준다.

\section{Tyrosinase 활성 측정}

Tyrosinase 활성은 Masamoto 등[23]의 실험 방법에 준하여 측정하였다. In vitro mushroom tyrosinase 저해 활성을 측정 하기 위하여 $2.5 \mathrm{mM}$ 3,4-dihydroxyphenylalanine (L-DOPA) $0.3 \mathrm{ml}$, 발효 당귀 분말의 $0.1 \%(\mathrm{w} / \mathrm{v})$ 시료 용액 $0.05 \mathrm{ml}$ 에 0.1 $\mathrm{M}$ 인산완충용액 $\left(\mathrm{pH}\right.$ 6.8)을 혼합하여 $25^{\circ} \mathrm{C}$ 에서 preincubation 시키고, 여기에 1,380 units/ml mushroom tyrosinase $(2,500$ unit, Sigma, St. Louis MO, USA) $0.05 \mathrm{ml}$ 를 넣은 후 $25^{\circ} \mathrm{C}$ 에서 2분간 반응시키면서 spectrophotometer (HITACHI U-2900, Kyoto, Japan)의 $475 \mathrm{~nm}$ 에서 흡광도를 측정하여 계산하였다. 대조구는 시료가 들어있지 않는 시료 용해 용액을 사용하였 고, 양성 대조구는 tyrosinase 저해제로 알려진 albutin, ascorbic acid 및 kojic acid를 사용하였다. 이때 tyrosinase 활성 저 해율 $(\%)$ 은 다음의 공식에 의하여 산출하였다.

Tyrosinase 활성 저해율 $(\%)=100-[(\mathrm{A}-\mathrm{B}) / \mathrm{A}] \times 100$

$\mathrm{A}$ 는 시료가 들어있지 않은 반응액의 0.5-1분 사이의 흡광도 차이 $\mathrm{B}$ 는 시료가 들어있는 반응액의 0.5-1분 사이의 흡광도 차이

\section{통계처리}

실험으로부터 얻어진 결과치는 one-way ANOVA 검정에 의한 평균치와 표준오차(mean $\pm \mathrm{SE}$ 로 표시하였다[10].

\section{결과 및 고찰}

\section{참당귀 뿌리의 발효 및 decursin과 decursinol angelate 함량}

최근 들어 유산균, 효모, 고초균, 곰팡이 등 사람들에 유익한 미생물 또는 상황, 송이, 차가 버섯 등의 균사체를 이용한 발효 기술 진보로 천연물의 생리활성 효능이 증가된 발효 산물을 얻거나 또는 상호간의 상승 효과에 의해 생리활성 효능이 증 가 되어진 제품들이 개발되기 시작하였다[6,7]. 뽕잎 추출물을 동충하초 균사체로 발효시킴으로서 세포 독성작용이 경감하 고 tyrosinase 활성 저해에 의한 멜라닌 생성 억제 작용으로 미백효과가 더욱 증가되었다고 하였으며[30], 인삼의 주요 약 리적 성분중 하나로 고가에 판매되고 있는 compound $\mathrm{K}$ 도 Thermus caldophilus GK24 및 Cladosporium fuloum 균주로 발효 시킴으로서 그 균이 분비하는 효소인 B-glucosidase 작용으로 ginsenosides $\mathrm{Rb} 1, \mathrm{Rb} 2$ 및 $\mathrm{Rc}$ 로부터 생성 되었다[35].

이에 본 연구에서도 참당귀 뿌리에 탄수화물(68.75\%)이 많 이 함유된 점을 감안하여 당질 분해력이 높은 A. oryzae, A. kawachii 및 M. purpureus 균주를 접종하여 발효시킴으로서 생 리활성 성분 및 효능 역시 증가될 수 있을 가능성에 대하여 검토하였다[26]. 특히 국내에서 자생되고 있는 참당귀의 대표 적인 약효 성분인 decursin 및 decursinol angelate는 부위별, 산지별 및 추출 방법에 따라서도 함량이 달라지는 것으로 분 석되었으며[13,20,32,33], decursin과 decursinol angelate 분자 량이 각각 329 및 351 로 확인되었다[20]. 본 실험에서 참당귀 뿌리의 decursin과 decursinol angelate를 분석한 결과 총 면적 에 대한 이들의 함량 비율은 각각 44.0 및 $27.3 \%$ 로서 뿌리에 decursin이 많이 함유되어 있다고 하는 다른 연구자들의 결과 와 일치하였다[20,33]. 한편 A. oryzae, A. kawachii 및 M. purpureus 균주로 발효시킨 당귀에서는 decursin 함량비율이 각 각 52.0, 54.4 및 53.7\%로 모두 발효에 의해 증가되었으나, decursinol angelate 함량비율은 각각 27.9, 27.5 및 28.2\%로 decursin과는 달리 발효에 의한 변화는 없었다(Table 2). 당귀의 주요 약리적 성분인 decursin이 미생물 발효에 의해 증가된 것은 발효 과정 중에 다른 물질로부터 전환되었을 가능성과 효소적 작용으로 성분 상호간의 결합이 분해되면서 용출이 용이해져 함량이 증가되었을 가능성이 있지만 정확한 기작에 대해서는 좀 더 심도 있는 검토가 있어야 할 것으로 사료되어 진다.

\section{Polyphenolic compounds 함량}

본 실험에서 사용한 참당귀 뿌리의 polyphenolic compounds 함량은 $2.78 \%$ 였으나, A. oryzae, A. kawachii 및 M. purpureus 균주로 발효시킨 발효당귀에서는 각각 2.36, 2.42 및 $2.32 \%$ 로 나타나, 발효에 의해 약간씩 낮아진 결과를 얻었다 
Table 2. Content analysis by HPLC chromatogram of decursin and decursinol angelate in fermented Angelic gigas by mold

\begin{tabular}{llcccc}
\hline Strain & Name & RT & Height & Area & Area (\%) \\
\hline \multirow{2}{*}{ Non-fermented } & Decursin & 42.86 & 1,107 & 22,470 & 44.0 \\
& Decursinol angelate & 43.23 & 2,194 & 13,969 & 27.3 \\
\cline { 2 - 6 } Aspergillus oryzae & Decursin & 42.76 & 1,528 & 36,566 & 52.0 \\
\multirow{2}{*}{ Aspergillus kawachii } & Decursinol angelate & 43.21 & 2,724 & 19,613 & 27.9 \\
\cline { 2 - 6 } & Decursin & 42.55 & 1,825 & 44,696 & 54.4 \\
Monascus purpureus & Decursinol angelate & 43.17 & 2,792 & 22,613 & 27.5 \\
\cline { 2 - 6 } & Decursin & 42.64 & 1,537 & 39,845 & 53.7 \\
\hline
\end{tabular}

Non-fermentedAspergillus oryzaeAspergillus kawachiiMonascus purpureusRT: Retention time

(Table 3). 국내산 식용식물 자원 중 뿌리 부분의 페놀성 화합 물 함량을 분석한 결과 쇠무릎 $1.67 \%$, 갈근 $2.01 \%$, 천궁 $1.57 \%$, 황기 $1.33 \%$ 및 인삼 $0.40 \%$ 가 함유되어 있었다[18,21]. 또한, 항산화 활성을 나타낸 당귀 뿌리에서도 폴리페놀 화합물이 $1.48 \%$ 함유되어 있었으며[18], 일본산 당귀 뿌리에서는 페놀 성 화합물의 일종인 타닌 함량이 $0.53 \%$ 함유되어 있었다고 하였다[26]. 본 연구자들도 한방 생약재 중에 들어있는 폴리페 놀 화합물 함량의 변화를 관찰하기 위하여 버섯 균사체로 40 종의 한방 생약재의 열수 추출물을 발효시킨 결과 14 종에서만 증가하였고, 나머지 26종에서는 감소한 것으로 나타났는데, 당귀의 경우도 발효에 의해 낮은 농도를 나타내어 발효에 의 해 대부분 페놀성 화합물 함량이 낮아지는 것으로 사료되어진 다[8]. 이러한 이유는 페놀성 화합물을 많이 함유하고 있는 식 물체 추출물 사용에 의한 세포독성 작용이 추출물의 발효에 의해 독성 작용이 경감되는 것과 무관하지 않을 것으로 추측 되어진다[30]. 그러나 Monasuc-발효 대두 경우 발효 30일 경과 후 페놀성 화합물 함량이 4.6 에서 $7.5 \mathrm{mg}$ 으로 증가하였고, 발 효 쌀의 경우 1.4 에서 $3.8 \mathrm{mg}$ 으로 증가한 것으로 나타나 본 실험 결과와는 다른 양상을 보였다[31].

\section{Flavonoid 함량}

식물체에 함유되어 있는 flavonoid는 항균 활성, 항산화 효 과, 항염 작용, 콜레스테롤 저하작용, 지방간 억제 작용 등이 보고되어 있으며, 종양 세포 성장 및 분화 억제 효과 등이 다수 보고되어 있다 $[9,18]$. 약용 식물 중 flavonoid 함량은 땅두릅 $1.13 \%$ 및 땅두릅잎 $1.54 \%$, 황기 $1.53 \%$, 맥문동 $0.69 \%$, 소엽 $1.92 \%$, 갈근 $1.08 \%$ 및 오미자 $0.66 \%$ 가 함유되어 있다고 보고 하였다[9,11]. 본 연구 결과에서는 당귀 뿌리에 flavonoid가 $1.03 \%$ 함유되었으나, A. oryzae, A. kawachii 및 M. purpureus 균주로 발효시킨 발효당귀에서는 각각 $0.90,1.04$ 및 $1.18 \%$ 함 유되어 있었다(Table 3). 다른 연구자들은 당귀 뿌리의 flavonoid 함량이 수용성 추출물 중에는 $0.72 \%$ 함유되어 있었고 [18], 메탄올 추출물 중에는 $2.35 \%$ 함유되어 있다고[11] 하여 추출 용매에 따라 함량이 달라지는 것으로 나타났다. 대부분 의 식물체에서 polyphenolic compounds 함량이 flavonoids
Table 3. Concentrations of polyphenolic compounds and flavonoids in fermented Angelic gigas by mold

\begin{tabular}{lcc}
\hline Strain & $\begin{array}{c}\text { Polyphenolic } \\
\text { compounds (\%) }\end{array}$ & $\begin{array}{c}\text { Flavonoids } \\
(\%)\end{array}$ \\
\hline Non-fermented & $2.78 \pm 0.00^{\mathrm{a}}$ & $1.03 \pm 0.01^{\mathrm{NS}}$ \\
Aspergillus oryzae & $2.36 \pm 0.01^{\mathrm{b}}$ & $0.90 \pm 0.06$ \\
Aspergillus kawachii & $2.42 \pm 0.01^{\mathrm{ab}}$ & $1.04 \pm 0.03$ \\
Monascus purpureus & $2.32 \pm 0.02^{\mathrm{b}}$ & $1.18 \pm 0.01$ \\
\hline
\end{tabular}

Values are mean $\pm S E, n=3$.

Values with different letters are significantly different at $p<0.05$. NS: Not significant.

보다 많이 함유 되어 있으며, 대체로 polyphenolic compounds 함량이 많은 식물이 flavonoids의 함량도 많이 함유하 고 있다[9,18]. 참당귀 뿌리에서도 polyphenolic compounds 함량이 flavonoids보다 2 배 이상 많아 flavonoids 이외의 다른 polyphenolic compounds가 함유되어 있는 것을 암시하는데, 황기, 오미자, 소엽, 맥문동, 갈근, 산수유, 오갈피, 음양곽, 해동 피에서도 비슷한 결과가 보고되었다[9,18].

\section{미네랄 함량}

국내산 참당귀 뿌리의 미네랄 성분 조성 비율을 보면 $\mathrm{K}$ 가 가장 많이 함유되어 있었고, 그 다음으로 $\mathrm{Mg}, \mathrm{Fe}, \mathrm{Ca}, \mathrm{Na}, \mathrm{Mn}$, $\mathrm{Zn}$ 순으로 함유되어 있었다(Table 4). 국내산 참당귀 뿌리를 A. oryzae, A. kawachii 및 M. purpureus 균주로 발효시킨 발효당 귀에서는 $\mathrm{Na}$ 을 제외하고 모두 증가한 것으로 나타났다(Table 4). 국내산 참당귀, 일본산 당귀, 중국산 당귀의 미네랄 분석 결과에서도 모두 $\mathrm{K}$ 가 각각 $329,283,223 \mathrm{ppm}$ 으로 가장 많이 함유되어 있었고, 그 다음으로 $\mathrm{Mg}, \mathrm{Fe}, \mathrm{Na}$ 순으로 함유되어 본 실험 결과와 일치하였다[22]. Hwang 등[13]의 국내산 참당 귀와 일본산당귀의 미네랄 분석 결과와 Kim과 Joung [19]의 참당귀 뿌리와 어린싹인 승검초의 미네랄 분석에서도 $\mathrm{K}$ 가 가 장 많이 함유되어 있어 본 실험 결과와도 일치하였다. 홍삼을 홍국균으로 발효시켜 미네랄 성분을 분석한 결과에서도 $\mathrm{Mg}$ 과 $\mathrm{Zn}$ 성분이 발효에 의해 증가되었다[27]. 또한 누에분말의 $\mathrm{Mg}$ 농도가 $44.3 \mathrm{ppm}$ 에서 A. oryzae, A. kawachii 및 M. purpur- 
Table 4. Concentrations of mineral in fermented Angelic gigas by mold

\begin{tabular}{ccccc}
\hline \multirow{2}{*}{ Minerals } & \multicolumn{4}{c}{ Mineral concentrations (ppm) } \\
\cline { 2 - 5 } & Non-fermented & Aspergillus oryzae & Aspergillus kawachii & Monascus purpureus \\
\hline $\mathrm{K}$ & $165.87 \pm 0.33^{\mathrm{a}}$ & $217.33 \pm 1.33^{\mathrm{c}}$ & $213.33 \pm 0.88^{\mathrm{d}}$ & $222.00 \pm 1.53^{\mathrm{b}}$ \\
$\mathrm{Mg}$ & $20.20 \pm 0.00^{\mathrm{a}}$ & $27.50 \pm 0.00^{\mathrm{c}}$ & $30.80 \pm 0.06^{\mathrm{d}}$ & $28.40 \pm 0.00^{\mathrm{b}}$ \\
$\mathrm{Fe}$ & $4.41 \pm 0.02^{\mathrm{a}}$ & $5.72 \pm 0.16^{\mathrm{c}}$ & $5.61 \pm 0.07^{\mathrm{c}}$ & $4.49 \pm 0.03^{\mathrm{b}}$ \\
$\mathrm{Na}$ & $3.07 \pm 0.48^{\mathrm{a}}$ & $0.37 \pm 0.01^{\mathrm{b}}$ & $0.95 \pm 0.00^{\mathrm{b}}$ & $0.56 \pm 0.00^{\mathrm{b}}$ \\
$\mathrm{Ca}$ & $2.20 \pm 0.01^{\mathrm{a}}$ & $3.61 \pm 1.00^{\mathrm{a}}$ & $2.77 \pm 0.00^{\mathrm{a}}$ & $2.63 \pm 0.01^{\mathrm{a}}$ \\
$\mathrm{Mn}$ & $0.81 \pm 0.00^{\mathrm{a}}$ & $1.19 \pm 0.00^{\mathrm{c}}$ & $1.24 \pm 0.00^{\mathrm{d}}$ & $1.18 \pm 0.00^{\mathrm{b}}$ \\
Zn & $0.25 \pm 0.00^{\mathrm{a}}$ & $0.35 \pm 0.00^{\mathrm{c}}$ & $0.29 \pm 0.00^{\mathrm{d}}$ & $0.37 \pm 0.00^{\mathrm{b}}$ \\
\hline
\end{tabular}

MineralsValues are mean $\pm \mathrm{SE}, \mathrm{n}=3$.

Values with different letters are significantly different at $p<0.05$.

eus 균주로 발효시킨 발효누에에서 각각 58.7, 44.3 및 53.7 $\mathrm{ppm}$ 으로 두 균주에서 증가하였으며, $\mathrm{Na}$ 의 경우는 $0.73 \mathrm{ppm}$ 에서 $0.06,0.07$ 및 $0.07 \mathrm{ppm}$ 으로 발효당귀에서와 같이 약 10 배 정도 감소하는 동일한 결과를 얻었다[7].

이상과 같이 당귀에 함유된 $\mathrm{K}, \mathrm{Mg}, \mathrm{Ca}, \mathrm{Fe}$ 등은 인체에 중요 한 필수 미네랄 성분으로 영양적인 측면에서도 매우 중요하 며, 또한 당귀는 생리불순, 무월경, 빈혈치료 등의 여성 혈관계 질환에도 널리 사용됨으로서 여성들에게 유효한 약재로 인식 되고 있어, 이를 이용한 여성용 건강지향 제품개발 소재로 활 용한다면 그 효용가치가 높아질 것으로 사료된다.

\section{$\mathrm{DPPH}$ 라디칼 전자공여능에 의한 항산화 활성}

Polyphenolic compounds 및 flavonoids 화합물의 항산화 활성을 간단히 측정할 수 있는 동시에 실제 항산화 활성과도 매우 연관성이 높기 때문에 DPPH 라디칼을 이용한 항산화 활성 측정 방법이 많이 이용되고 있다[5,15]. 과일, 야채, 곡물 중의 식물성 polyphenolic compounds 및 flavonoids와 같은 화합물과 항산화 활성 사이에는 높은 상관관계가 있다는 보고 가 있는 반면[37], 30종의 한방 생약재를 이용한 실험에서는 polyphenolic compounds 및 flavonoids 화합물과 DPPH radical scavenging 항산화 활성 또는 chelating effect 사이에서는 상관관계가 상당히 낮은 것으로 보고되었다[9].

본 실험에서 양성 대조군으로 사용한 시판 합성 항산화제인 BHT $0.05 \%$ 처리 농도에서는 $92 \%$ 로 $\mathrm{DPPH}$ 전자공여능에 의 한 항산화 활성이 높았으나, 동일 농도의 참당귀 뿌리의 항산
화 활성은 $19 \%$ 로 상당히 낮은 것으로 나타났다(Table 5). 약용 식물의 수용성 추출물 $0.1 \%$ 시료 농도에서 전자공여능에 의한 항산화 활성은 당귀 $15.8 \%$, 감초 $13.3 \%$, 옥죽 $5.4 \%$ 였으며[18], 메탄올 추출물에서는 당귀 $27.9 \%$, 황기 $10.4 \%$, 맥문동 $8.1 \%$, 소엽 $53.3 \%$, 갈근 $51.4 \%$, 오미자 $18.9 \%$ 로 당귀의 항산화 활성 은 본 실험 결과와 비슷하였다[9]. 그러나 참당귀 뿌리를 $A$. oryzae, A. kawachii 및 M. purpureus 균주로 발효시킨 발효당귀 에서는 항산화 활성이 각각 46,49 및 $56 \%$ 로 모두 2배 이상 증가한 것으로 나타났다(Table 5). 이러한 $\mathrm{DPPH}$ 전자공여능 에 의한 항산화 활성이 누에 분말에 비해 A. oryzae, A. kawachii 및 M. purpureus 균주로 발효시킨 발효 누에에서 모두 증가된 보고도 있다[7].

대부분의 식물체 추출물에서 polyphenolic compounds 및 flavonoids 성분의 함량이 높으면 항산화 활성이 높다는 상관 관계를 보여주지만[18], 일부에 있어서는 polyphenolic compounds 또는 flavonoids 화합물 함량은 높으나 항산화 활성이 낮은 경우도 보고되고 있고[24], 발효 당귀의 경우도 polyphenolic compounds 및 flavonoids 함량이 증가하지 않았음 에도 불구하고 항산화 활성이 증가한 것으로 나타나 발효액 중에 polyphenolic compounds 또는 flavonoids 이외의 활성 성분이 존재할 가능성을 시사하고 있다.

\section{환원력 활성}

환원력(reducing power) 활성 정도는 수소 원자를 제공하 는 유리 라디칼의 연쇄 반응으로 금속 이온을 환원시키는 정

Table 5. DPPH free radical scavenging activities in fermented Angelic gigas by mold

\begin{tabular}{lcc}
\hline Strain & Conc. $(\%)$ & Radical scavenging activities $(\%)$ \\
\hline BHT & 0.05 & $92.35 \pm 0.05^{\mathrm{a}}$ \\
Non-fermented & 0.05 & $19.01 \pm 0.08^{\mathrm{b}}$ \\
Aspergillus oryzae & 0.05 & $46.39 \pm 0.65^{\mathrm{c}}$ \\
Aspergillus kawachii & 0.05 & $48.97 \pm 0.69^{\mathrm{d}}$ \\
Monascus purpureus & 0.05 & $55.87 \pm 0.08^{\mathrm{e}}$ \\
\hline
\end{tabular}

BHT: butylated hydroxytoluene.

Values are mean $\pm S E, n=3$.

Values with different letters are significantly different at $p<0.05$. 
도를 흡광도 값으로 나타내는 것으로, 환원력의 세기가 높을 수록 항산화 활성이 높다는 것을 나타내어 준다. $\mathrm{Fe}$-환원력은 대조구로 사용한 BHT 및 ascorbic acid $0.05 \%$ 의 농도 처리에 서 1.469 및 1.485의 흡광도를 나타내어 가장 높았다(Table 6). 당귀 뿌리 $0.05 \%$ 처리농도의 $\mathrm{Fe}$-환원력은 0.066 에 비해 A. oryzae, A. kawachii 및 M. purpureus 균주로 발효시킨 발효 당귀 에서는 각각 $0.036,0.051$ 및 0.036 으로 발효에 의해 다소 낮아 지는 경향을 보였다(Table 6). 또한 $\mathrm{Cu}$-환원력은 대조구로 사 용한 BHT 및 ascorbic acid $0.05 \%$ 의 농도 처리에서 1.436 및 1.749 의 흡광도를 나타내어 가장 높았으며, A. oryzae, A. kawachii 및 M. purpureus 균주로 발효시킨 발효 당귀에서는 각 각 $0.061,0.084$ 및 0.065 로 발효에 의해 $\mathrm{Fe}$-환원력과 마찬가지 로 낮아지는 경향을 보였다. 한방 생약재인 원료 복령 및 후박 추출물의 환원력은 각각 $0.55-0.63$ 및 0.98-1.06에 비해 버섯 균사체로 발효시킨 발효 복령 및 후박의 환원력은 0.50-0.62 및 0.76-1.01로 발효에 의해 환원력이 다소 떨어지는 것으로 나타나[34], 본 실험 결과와도 일치하였다. 그러나 더덕의 경우 열수 추출물 $0.1 \%$ 처리 농도에서 환원력으로 측정한 흡광도는 0.34 인데 발효 더덕의 경우 0.65 값으로 발효에 의해 활성이 증가된 것으로 나타나 본 실험 결과와는 다른 양상을 보였다 [29]. 이러한 차이는 발효 더덕의 경우 총 페놀 및 플라보노이 드 함량이 생더덕 보다 많이 함유됨으로서 환원력 활성이 증 가된 것으로 보여 지지만, 본 연구에서는 이들 두 성분이 발효 에 의해 증가되지 않았기 때문인 것으로 사료 되어진다.

\section{Tyrosinase 활성}

피부, 머리카락, 눈동자 등의 색소 구성 성분인 멜라닌은 인체 내에서 표피층의 melanocyte라는 색소세포 내의 melanosome에서 합성되는데, tyrosine을 시발 물질로 하여 tyrosinase 효소에 의해 DOPA (3,4-dihydroxy-phenylalanine) 또는 DOPA quinone으로 산화 및 중합 반응에 의해 합성 된다 [37]. 이때 생성되는 멜라닌은 정상적인 상태에서는 자외선과 같은 피부자극에 대해 저항력을 높여주지만, 과도하게 생합성 된 멜라닌은 기미, 주근깨, 검버섯과 같은 색소 침착과 피부 손상을 일으키고 있다. 이때 피부 미백효과를 측정하는 하나
의 지표로 tyrosinase 활성을 측정하고 이를 효과적으로 저해 하는 생리활성물질을 탐색하는 것이 화장품 산업에서 매우 중요한 부분이다. 멜라노마 세포 증식과 멜라닌 생합성을 억 제시키는 대표적인 화합물 중에 phenolic compounds, flavonoid, arbutin, glycolic acid, kojic acid, pentadecenoic acid, ferulic acid, isoflavonoids 등이 제시되고 있다[4,16]. 국내에 서 자생하고 있는 한방 생약재 중에서 수용성 추출물인 상백 피 $63 \%$, 감초 $13-52 \%$, 작약 $44 \%$, 천궁 $28 \%$, 복령 $4 \%$ 의 tyrosinase 활성 저해효과가 보고되었다[16]. 또한 Jee [14]는 상 백피 열수 및 에탄올 추출물의 $0.2 \%$ 처리 농도에서 tyrosinase 활성이 각각 80 및 $93 \%$ 의 억제 효과를 보였으며, Jung 등[16] 은 상백피, 계피, 갈근 추출물 $0.2 \%$ 처리 농도에서 tyrosinase 활성이 각각 $63,81,59 \%$ 억제되었다고 보고 하였다. 본 실험에 서도 양성 대조구로 사용한 albutin, ascorbic acid, kojic acid의 $0.1 \%$ 처리 농도에서 tyrosinase 저해 활성이 각각 76,73 및 $77 \%$ 로 Kim 등[17]이 동일 농도로 처리한 ascorbic acid에 의해 $71 \%$ 의 저해 활성 결과와 비슷한 수준을 나타내었다. 그러나 당귀 뿌리 추출물의 tyrosinase 저해 활성은 $18 \%$ 로 상당히 낮 았으나, A. oryzae, A. kawachii 및 M. purpureus 균주로 발효시 킨 발효 당귀에서는 각각 34,37 및 $45 \%$ 로 2 배 이상 증가한 것으로 나타났다(Table 7). Kim 등[17]도 초고압으로 추출한 당귀 추출물 $1 \mathrm{mg} / \mathrm{ml}$ 농도에서 $69.4 \%$ 로 처리 농도 의존적으 로 활성 저해 효과가 있었으며, Jung 등[16]도 당귀 수용성 추 출물에 tyrosinase 저해 활성이 $39 \%$ 라고 보고하였다. Park 등 [30]은 뽕잎의 $50 \%$ 착즙액을 tyrosinase 활성 측정의 반응액에 $50 \%$ 까지 처리시 $20 \%$ 의 활성 저해 효과가 있었으나, 이를 동충 하초 균사체로 발효시킨 배양액에서는 $20 \%$ 처리시 $30 \%$ 의 활 성 저해가 있었고, $50 \%$ 처리에 의해서는 $100 \%$ 활성을 억제시 키는 결과를 얻음으로서 발효에 의해 tyrosinase 활성 저해 효과가 증가한 것으로 나타났다. 한편 B16BL6 mouse melano$\mathrm{ma}$ cell을 이용하여 멜라닌 생합성 억제율을 측정한 결과 뽕잎 $50 \%$ 착즙액에 동충하초 균사체로 발효시킨 발효액 $10 \%$ 처리 시 $60 \%, 20 \%$ 처리시 $80 \%$ 의 효과와 더불어 세포독성이 전혀 없다고 하였으나, 뽕잎 착즙액 그 자체는 멜라닌 생합성 억제 율이 낮으면서 세포독성이 강하게 나타나 발효에 의해 세포

Table 6. Reducing power in fermented Angelic gigas by mold

\begin{tabular}{lccc}
\hline \multirow{2}{*}{ Strain } & \multirow{2}{*}{ Conc.(\%) } & \multicolumn{2}{c}{ Reducing power (Optical density at $700 \mathrm{~nm}$ ) } \\
\cline { 3 - 4 } & 0.05 & Fe & $1.436 \pm 0.01^{\mathrm{a}}$ \\
BHT & 0.05 & $1.469 \pm 0.06^{\mathrm{a}}$ & $1.749 \pm 0.01^{\mathrm{b}}$ \\
Ascorbic acid & 0.05 & $1.485 \pm 0.01^{\mathrm{a}}$ & $0.085 \pm 0.00^{\mathrm{ce}}$ \\
Non-fermented & 0.05 & $0.066 \pm 0.00^{\mathrm{b}}$ & $0.061 \pm 0.00^{\mathrm{d}}$ \\
Aspergillus oryzae & 0.05 & $0.036 \pm 0.00^{\mathrm{b}}$ & $0.084 \pm 0.00^{\mathrm{c}}$ \\
Aspergillus kawachii & 0.05 & $0.051 \pm 0.00^{\mathrm{b}}$ & $0.065 \pm 0.00^{\mathrm{de}}$ \\
Monascus purpureus & & $0.036 \pm 0.00^{\mathrm{b}}$ & \\
\hline
\end{tabular}

StrainConc.(\%)BHT: butylated hydroxytoluene.

Values are mean $\pm S E, n=3$.

Values with different letters are significantly different at $p<0.05$. 
Table 7. Inhibition activity of tyrosinase in fermented Angelic gigas by mold

\begin{tabular}{lcc}
\hline Strain & Conc. (\%) & Tyrosinase inhibition activity (\%) \\
\hline Control & - & $100.00 \pm 5.86^{\mathrm{a}}$ \\
Arbutin & 0.1 & $76.04 \pm 2.50^{\mathrm{b}}$ \\
Ascorbic acid & 0.1 & $72.59 \pm 1.98^{\mathrm{b}}$ \\
Kojic acid & 0.1 & $77.23 \pm 2.27^{\mathrm{b}}$ \\
Non-fermented & 0.1 & $18.00 \pm 0.98^{\mathrm{d}}$ \\
Aspergillus oryzae & 0.1 & $34.33 \pm 1.34^{\mathrm{c}}$ \\
Aspergillus kawachii & 0.1 & $36.59 \pm 1.24^{\mathrm{c}}$ \\
Monascus purpureus & 0.1 & $44.46 \pm 2.37^{\mathrm{c}}$ \\
\hline
\end{tabular}

Values are mean $\pm S E, n=3$.

Values with different letters are significantly different at $p<0.05$.

독성 경감, tyrosinase 활성 저해, 멜라닌 생합성 억제 작용이 증가한다고 하였다[30]. 또한 Ahn 등[3]은 라벤더 추출물의 ethyl acetate 분획과 자연 미생물 발효 추출물의 ethyl acetate 분획에서 tyrosinase 활성 저해 효과( $\left(\mathrm{IC}_{50}\right)$ 는 각각 145 및 122 $\mu \mathrm{g} / \mathrm{ml}$ 로 발효에 의해서 활성이 높았다고 하였고, Yang 등[39] 도 레몬밤 추출물과 발효 추출물의 경우 tyrosinase 저해 활성 $\left(\mathrm{IC}_{50}\right)$ 이 각각 365 및 $122 \mu \mathrm{g} / \mathrm{ml}$ 으로 역시 발효에 의해 활성 저해작용이 높아졌다고 하였다. 따라서 한방 생약재 유래의 미백 기능성 화장품 개발을 위해서는 추출물 사용보다는 미생 물 또는 균사체로 발효시켜 사용함으로서 세포 독성 경감, tyrosinase 활성 저해, 멜라닌 생합성 억제 작용과 같은 효과를 기대 할 수 있을 것으로 사료 되어진다.

\section{감사의 글}

본 연구는 동아대학교 연구비 지원에 의해 이루어졌습니다.

\section{References}

1. Abe, N., T. Murata, and A. Hirota. 1998. Novel DPPH radical scavengers, bisorbicillinol and demethyltrichodimerol, from a fungus. Biosci. Biotechnol. Biochem. 62, 661-666.

2. Ahn, M. J., M. K. Lee, Y. C. Kim, and S. H. Sung. 2008. The simultaneous determination of coumarins in Angelica gigas root by high performance liquid chromatography-diode array detector coupled with electrospray ionization/mass spectrometry. J. Pharm. Biomed. Anal. 46, 258-266.

3. Ahn, Y. J., B. R. Won, M. K. Kang, J. H. Kim, and S. N. Park. 2009. Antioxidant activity and component analysis of fermented Lavamdula angustifolia extracts. J. Soc. Cosmet. Scientists Korea 35, 125-134.

4. Cabanes, J., S. Chazarra, and F. Garcia-Carmona. 1994. Kojic acid, a cosmetic skin whitening agent, is a slow binding inhibitor of catecholase activity of tyrosinase. J. Pharm. Pharmacol. 46, 982-985.

5. Cha, J. Y., H. J. Kim, C. H. Chung, and Y. S. Cho. 1999. Antioxidative activities and contents of polyphenolic com- pound of Cudrania tricuspidata. J. Korean Soc. Food Sci. Nutr. 28, 1310-1315.

6. Cha, J. Y., H. Y. Ahn, K. E. Eom, B. K. Park, B. S. Jun, J. C. Park, C. H. Lee, and Y. S. Cho. 2009. Effects of Monascus-fermented Korean red ginseng powder on the contents of serum lipid and tissue lipid peroxidation in alcohol feeding rats. J. Life Sci. 19, 983-993.

7. Cha, J. Y., Y. S. Kim, P. D. Kang, H. Y. Ahn, K. E. Eom, and Y. S. Cho. 2010. Biological activity and chemical characteristics of fermented silkworm powder by mold. J. Life Sci. 20, 237-244.

8. Cha, J. Y., H. J. Yang, J. J. Jeong, W. S. Seo, J. S. Park, M. Ok, and Y. S. Cho. 2010. Tyrosinase inhibition activity and antioxidant capacity by fermented products of some medicinal plants. J. Life Sci. 20, 940-947.

9. Choi, Y. M., J. B. Gu, M. H. Kim, and J. S. Lee. 2008. Antioxidant and antiproliferative activities of methanolic extracts from thirty Korean medicinal plants. Food Sci. Biotechnol. 17, 1235-1239.

10. Duncan, D. B. 1959. Multiple range and multiple F test. Biometrics 1, 1-42.

11. Han, G. J., D. S. Shin, and M. S. Jang. 2008. A study of the nutritional composition of Aralica continentalis Kitagawa and Aralica continentalis Kitagawa leaf. Korean J. Food Sci. Technol. 40, 680-685.

12. Hong, M. W. 1972. Statistical studies on the formularies of oriental medicine (I) prescription frequency and their origin distribution of herb drugs. Korean J. Pharmacog. 3, 57-64.

13. Hwang, J. B. and M. O. Yang. 1997. Comparison of chemical components of Angelica gigas Nakai and Angelica acutiloba Kitagawa. Korean J. Food Sci. Technol. 29, 1113-1118.

14. Jee, S. O. 2009. Antioxidant activities and whitening effect of the mulberry (Morus alba L.) root bark extracts. Korean J. Plant Res. 22, 145-151.

15. Jia, Z., M. Tang, and J. Wu. 1999. The determination of flavonoid contents in mulberry and thier scavenging effects on superoxide radicals. Food Chem. 64, 555-559.

16. Jung, S. W., N. K. Lee, S. J. Kim, and D. S. Han. 1995. Screening of tyrosinase inhibitor from plants. Korean J. Food Sci. Technol. 27, 891-896.

17. Kim, C. H., M. C. Kwon, H. G. Han, C. S. Na, H. G. Kwak, 
G. P. Choi, U. Y. Park, and H. Y. Lee. 2008. Skin-whitening and UV-protective effects of Angelica gigas Nakai extracts on ultra high pressure extraction process. Korean J. Medicinal Crop Sci. 16, 255-260.

18. Kim, E. Y., I. H. Baik, J. H. Kim, S. R. Kim, and M. R. Rhyu. 2004. Screening of the antioxidant activity of some medicinal plants. Korean J. Food Sci. Technol. 36, 333-338.

19. Kim, H. S. and S. W. Joung. 2006. Effective components and nitrile scavenging ability of root and leaves a Angelica gigas Nakai. Korean J. Food Cookery Sci. 22, 957-965.

20. Kim, K. M., J. Y. Jung, S. W. Hwang, M. J. Kim, and J. S. Kang. 2009. Isolation and purification of decursin and decursinol angelate in Angelica gigas Nakai. J. Korean Soc. Food Sci. Nutr. 38, 653-656.

21. Lee, J. H. and S. R. Lee. 1994. Analysis of phenolic substances content on Korea plant foods. Korean J. Food Sci. Technol. 26, 310-316.

22. Lee, J. J., A. R. Kim, Y. N. Seo, and M. Y. Lee. 2009. Comparison of physicochemical composition of three species of genus Angelica. Korean J. Food Preserv. 16, 94-100.

23. Masamoto, Y., H. Ando, Y. Murata, Y. Shimoishi, M. Tada, and K. Takahata. 2003. Mushroom tyrosinase inhibitory activity of esculetin isolated from seeds of Euphorbia lathyris L. Biosci. Biotechnol. Biochem. 67, 631-634.

24. Maxson, E. and L. Rooney. 1972. Evaluation of methods for tannin analysis in sorghum grain. Cereal Chem. 49, 719-729.

25. Oh, S. H., Y. S. Cha, and D. S. Choi. 1999. Effects of Angelica gigas Nakai diet on lipid metabolism, alcohol metabolism and liver function of rats administered with chronic ethanol. J. Korean Soc. Agric. Chem. Biotechnol. 42, 29-33.

26. Oh, S. L., S. S. Kim, B. Y. Min, and D. H. Chung. 1990. Composition of free sugars, free amino acids, non-volatile organic acids and tannins in the extracts of L. chinensis M., A. acutiloba K., S. chinesis B. and A. sessiliflorum S. Korean J. Food Sci. Technol. 22, 76-81.

27. Park, J. C., J. Y. Cha, C. H. Lee, E. S. Doh, I. K. Kang, and Y. S. Cho. 2009. Biological activities and chemical characteristics of Monascus-fermented Korea red ginseng. J. Life Sci. 19, 1553-1561.

28. Park, K. W., S. R. Choi, M. E. Shon, I. Y. Jeong, K. S. Kang, S. T. Lee, K. H. Shim, and K. I. Seo. 2007. Cytotoxic effects of decursin from Angelica gigas Nakai in human cancer cells. J. Korean Soc. Food Sci. Nutr. 36, 1385-1390.

29. Park, S. J., S. W. Song, D. H. Seong, D. S. Park, S. S. Kim, J. Gou, J. H. Ahn, W. B. Yoon, and H. Y. Lee. 2009. Biological activities in the extract if fermented Codonopsis lanceolata. J. Korean Soc. Food Sci. Nutr. 38, 983-988.

30. Park, S. S., Y. B. Ryu, Y. H. Lee, Y. U. Cho, S. J. Cho, Y. J. Choi, K. H. Park, and S. W. Gal. 2007. Inhibition of melanin synthesis by mycelial culture broth of Paecilomyces japonica in the mulberry leaf extract. J. Life Sci. 17, 816-821.

31. Pyo, Y. H. 2007. Comparison of antioxidant potentials in methanolic extracts from soybean and rice fermented with Monascus sp. Food Sci. Biotechnol. 16, 451-456.

32. Ryu, K. S., N, D, Hong, and Y. Y. Kim. 1990. Studies on the coumarin constituents of the root of Angelica gigas Nakai. Isolation of decursinol angelate and assay of decursinol angelate and decursin. Korean J. Pharmacogn. 21, 64-68.

33. Seong, N. S., S. W. Lee, K. S. Kim, and S. T. Lee. 1993. Environmental variation of decursin content in Angelica gigas. Korean J. Crop Sci. 38, 60-65.

34. Shon, M. E. 2007. Antioxidant and anticancer activities of Poria cocos and Machilus thunbergii fermented with mycelial mushrooms. Food Indus. Nutr. 12, 51-57.

35. Son, J. W., H. J. Kim, and D. K. Oh. 2008. Ginsenoside Rd production from the major ginsenoside $\mathrm{Rb}(1)$ by beta-glucosidase from Thermus caldophilus. Biotechnol. Lett. 30, 713-716.

36. Swain, T., W. E. Hillis, and M. Oritega. 1959. Phenolic constituents of Ptunus domestica. I. Quantitative analysis of phenolic constituents. J. Sci. Food Agric. 10, 83-88.

37. Vile, G. F. and R. M. Tyrrell. 1995. UVA radiation-induced oxidative damage to lipid and protein in vitro and in human skin fibroblast is dependent on iron and singlet oxygen. Free Radical Biol. Med. 18, 721-730.

38. Woo, K. S., I. G. Hwang, D. S. Song, Y. R. Lee, J. S. Lee, and H. S. Jeong. 2008. Changes in antioxidant activity of Rehmannia radix Libosch with heat treatment. Food Sci. Biotechnol. 17, 1387-1390.

39. Yang, H. J., E. H. Kim, J. O. Park, J. E. Kim, and S. N. Park. 2009. Antioxidative activity and component analysis of fermented Melissa officinalis extracts. J. Soc. Cosmet. Scientists Korea 35, 47-55.

40. Yang, H. J., E. H. Kim, J. O. Park, J. E. Kim, and S. N. Park. 2009. Antioxidant activity and component analysis of fermented Melissa officinalis extracts. J. Soc. Cosmet. Scientists Korea 35, 125-134.

41. Zhu, Q. V., R. M. Hackman, X. X. Jodilensunsa, R. R. Holt, and C. L. Keen. 2002. Antioxidative activities of Oolong tea. J. Agric. Food Chem. 50, 6229-6934. 


\section{초록 : 곰팡이 발효 참당귀의 유효성분 분석 및 생리활성 작용}

차재영 $\cdot$ 김현우 $\cdot$ 허진선 ${ }^{1} \cdot$ 안희영 ${ }^{2} \cdot$ 엄경은 $^{2} \cdot$ 허수진 $^{2} \cdot$ 조영수 $^{3 *}$

(대선주조(주) 기술연구소 ${ }^{1}$ (재)산청한방약초연구소 ${ }^{2}$ 동아대학교 대학원 의생명과학과 ${ }^{3}$ 동아대학교 생명공 학과)

국내산 참당귀의 생리활성 물질을 이용한 건강 기능성 식품 또는 화장품 소재 개발을 위한 기초연구의 일환으 로 참당귀 뿌리를 3종류의 곰팡이 균주, A. oryzae, A. kawachii 및 M. purpureus 균주로 발효시켜 polyphenolic compounds, flavonoids, minerals, decursin 및 decursinol angelate 함량 분석과 항산화, 환원력 및 tyrosinase 활 성을 측정 하였다. 참당귀 뿌리의 decursin과 decursinol angelate의 총 면적에 대한 함량 비율은 각각 44.0 및 $27.3 \%$ 였으며, 한편 A. oryzae, A. kawachii 및 M. purpureus에 의한 발효 당귀의 decursin 함량 비율은 각각 52.0, 54.4 및 $53.7 \%$ 였다. 참당귀 뿌리의 polyphenolic compounds 함량은 $2.78 \%$ 였으나 발효 당귀에서 모두 약간씩 감소하였고, flavonoid 함량은 $1.03 \%$ 함유되었으나 M. purpureus 발효 당귀에서 $1.18 \%$ 로 약간 증가하였다. 참당 귀 뿌리의 미네랄 조성은 $\mathrm{K}, \mathrm{Mg}, \mathrm{Fe}, \mathrm{Ca}, \mathrm{Na}, \mathrm{Mn}, \mathrm{Zn}$ 순이였으며, 발효당귀에서 $\mathrm{Na}$ 은 감소하고 나머지는 모두 증가하였다. 참당귀 뿌리의 항산화 활성 $19 \%$ 에 비해 A. oryzae, A. kawachii 및 M. purpureus 발효 당귀에서 각각 46,49 및 $56 \%$ 로 모두 2배 이상 증가하였다. $\mathrm{Fe}$ - 및 $\mathrm{Cu}$-환원력은 참당귀 뿌리보다 발효 당귀에서 모두 낮아지는 경향을 보였다. Tyrosinase 저해 활성은 당귀 뿌리의 $18 \%$ 에 비해 A. oryzae, A. kawachii 및 M. purpureus 발효 당귀에서 각각 34,37 및 $45 \%$ 로 발효에 의해 2 배 이상 증가하였다. 이상의 실험결과 발효 당귀에서 대표적인 화합 물인 decursin과 decursinol angelate 함량이 증가하고, 항산화 활성 및 tyrosinase 저해 활성이 증가됨으로서 이 를 활용한 건강기능 제품 개발 가능성이 높아졌으며, 이러한 제품 개발에 필요한 기초 자료를 제공해주는데 유용 하게 사용될 것이다. 